\title{
The Pineal Gland and its earliest physiological description
}

\section{Konstantinos Laios}

Medical School, National and Kapodistrian University of Athens, Greece

Dear Editor,

The earliest physiological description of the Pineal (Latin: pinea = pinecone) Gland (also occasionally "conarium", from the Greek: $\kappa \omega v \alpha ́ p l o=\kappa \omega ́ v o \varsigma=c o n e$, pinecone) is found in two medical works written by Galen $\left(2^{\text {nd }} \mathrm{c} . \mathrm{AD}\right)$ (Figure 1). These works contain its anatomical description as well as a description of the function, both physical and metaphysical, of the organ, as understood in ancient Greek medical thought, which was very different from the concept of modern medicine.

In his work De usu partium (On the Utility of the Parts of the Body), ${ }^{1}$ Galen described the location of the pineal gland, that is, directly behind what he termed "the middle ventricle" (now known as the third ventricle) at the beginning of the posterior cerebrum, and hypothesized that, like all other glands (Greek: 'A $\delta \dot{\eta} v$ ) of the body, it is a support for the surrounding blood vessels. He also explained that the gland had gained this appellation due to its shape which resembles a pinecone. Moreover, in line with numerous scholars and sages of ancient civilizations (e.g. Egyptian, Hindu), the physician stated that the

Key words: Conarium, Descartes, Galen, Oribasius of Pergamon, Pineal gland, Theophilus Protospatharius

Address for correspondence:

Konstantinos Laios MD, PhD, 1 Athinodorou Str., Kato Petralona, 118 53, Athens, Greece; Tel.: +30 6947091434, Fax: +30 2103474338, e-mail: konstlaios@gmail.com Received: 16-03-2017, Accepted: 30-03-2017 ventricles were channels of "psychic pneuma", "the first instrument of the soul". Galen also believed that the physiological role of the pineal gland is to fill up the bifurcation of the great vein of the cerebrum ("vein of Galen") from which nearly all the choroid plexuses of the anterior ventricles arise (Galen, De usu partium 3.674.14-3.675.19). We can moreover appreciate Galen's abilities as an anatomist for several reasons. In another of his works, De anatomicis administrationibus libri ix (On Anatomical Procedures, Book 9), ${ }^{2}$ emphasizing the extreme fragility of the pineal gland, he stressed the importance for the anatomist to avoid damaging this organ and to

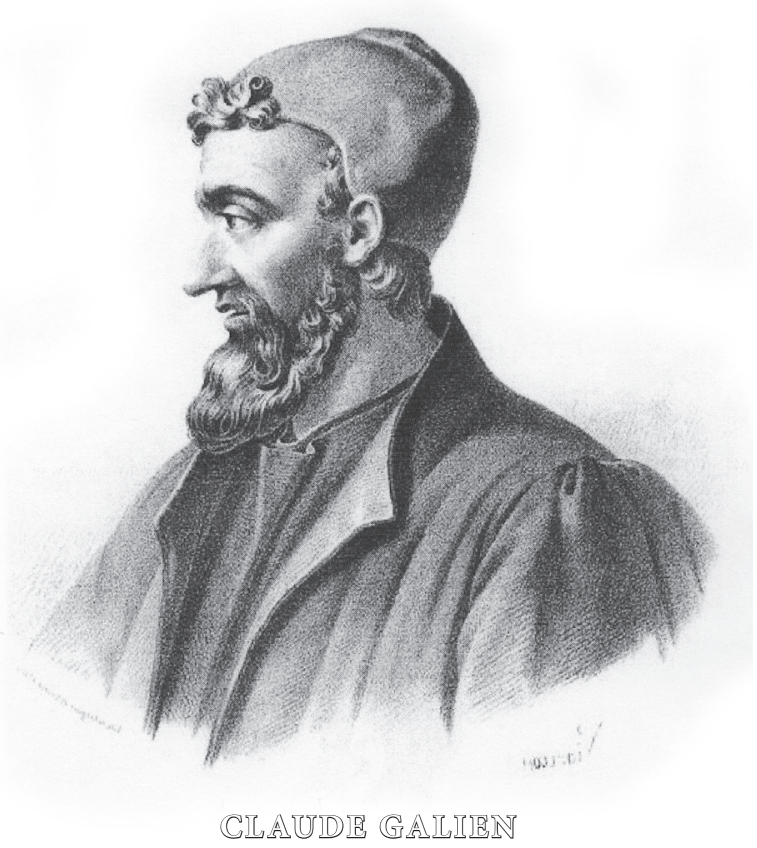

Figure 1. Galen (128-200 A.D.) 
aim to preserve it completely intact for the anatomy lesson (ibid, 2.723.3-2.730.2). In addition, he is not known to have ever executed a dissection on a human body, his main anatomical work being done on animals, sometimes on apes or monkeys. Of note, he strongly rejected a view of his time, namely, that this gland had a similar role to that of the pylorus: in other words, that in the manner that the pylorus regulates the passage of food from the stomach to the intestine, the pineal gland regulates the passage of the pneuma (air) to the cerebellum.

The first eminent Byzantine physician, Oribasius of Pergamon ( $4^{\text {th }}$ century A.D.) (Figure 2$)$, preserved Galen's views on the pineal gland (Collectiones medicae 24.1.22.1-24.1.23.5), ${ }^{3}$ while the later Byzantine physician Theophilus Protospatharius $\left(9 / 10^{\text {th }}\right.$ century AD) also followed Galen's teaching on this subject (De corporis humani fabrica libri quinque 4.7.17-4.7.27). ${ }^{4}$ The first pictorial representation of the pineal gland is credited to Andreas Vesalius (1514-1564) (Figure 3 ), while it is noteworthy that Girolamo Fracastoro (1476/8-1553) questioned its role as a simple 'mechanical' valve, reintroducing instead the ancient idea that this organ is the seat of "reasoning", that is to say of intuition, of wisdom.

Very similarly, René Descartes (1596-1650) (Figure 4) echoed the ancient belief that the pineal gland is the seat of the soul. Though he knew that animals too have a pineal gland, he pointed out that in the human the pineal gland acts in a totally unique manner, namely, functioning as the principal seat of the soul, that is, the source of human reason or wisdom. These

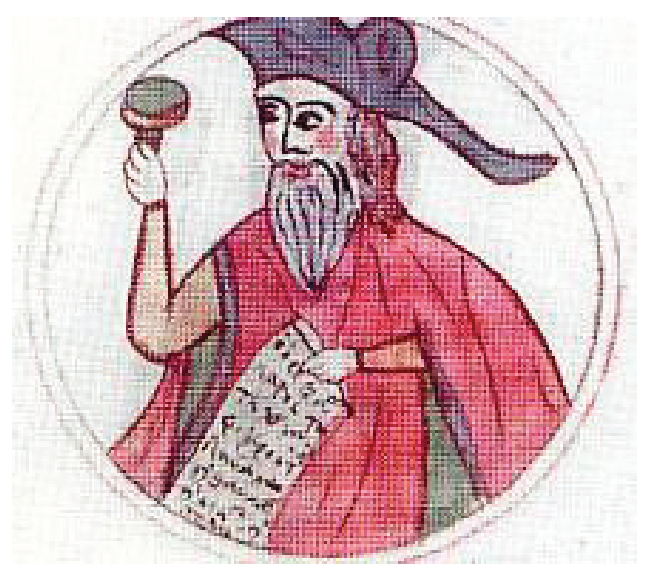

Figure 2. Oribasius of Pergamon.

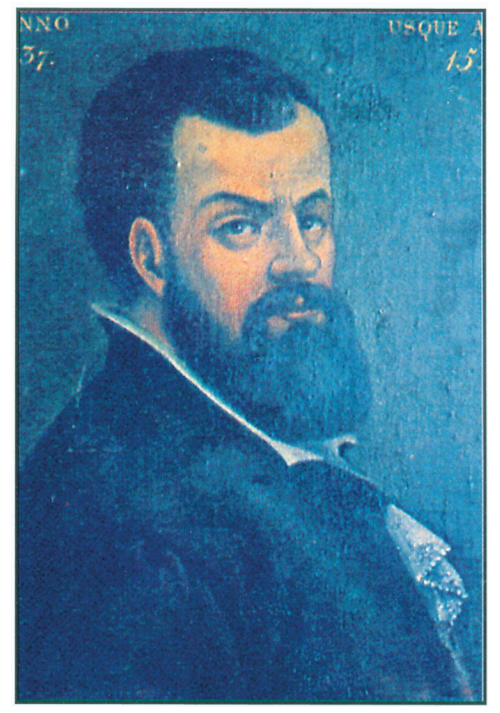

Figure 3. Andrea Vesalius, University of Padua, Spain.

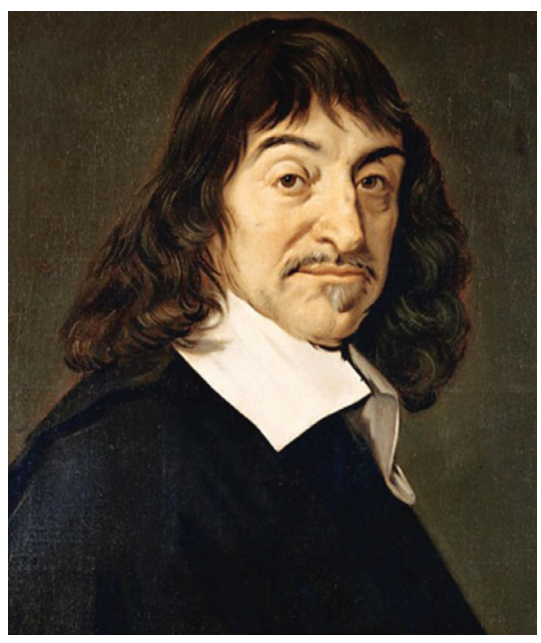

Figure 4. René Descartes.

metaphysical ideas were also entertained by several of the ancient Greek philosophers and, as mentioned, by scholars and sages throughout the ancient world.

In the modern age, evolutionary biology has demonstrated that almost all vertebrate species possess a pineal gland, which first appeared approximately 500 million years ago in reptiles. Among many others of his time, Antoine Jacques Louis Jourdain (1788-1848) rejected Descartes' views and, as from the mid-19 $9^{\text {th }}$ century, all emphasis has been placed on scientific discoveries in the histology, pathology and biochemistry of the pineal gland, focusing exclusively on its physiological role in the human body. Of interest in 
particular are the anatomical studies carried out in the $19^{\text {th }}$ and $20^{\text {th }}$ centuries on the pineal gland by Stieda Lydwig (1837-1918) and the pathologoanatomical studies by Giulio Bizzozero (1846-1901). The full understanding of the role of this gland as an endocrine organ was achieved in the mid- $20^{\text {th }}$ century after the isolation of melatonin by Aaron B. Lerner (1920-2007) in 1958 and the discovery of its role in circadian rhythm by Julius Axelrod (1912-2004) during 1960-1965. ${ }^{7}$

\section{CONFLICT OF INTEREST}

The author declares that there is no conflict of interest.

\section{REFERENCES}

1. Helmreich G, 1907 Galeni de usu partium libri xvii. Leipzig: Teubner.

2. Kühn CG, 1821 Claudii Galeni opera omnia, vol. 2. Leipzig: Knobloch.

3. Raeder J, 1928 Oribasii collectionum medicarum reliquiae. Leipzig: Teubner.

4. Greenhill GA, 1842 Theophili Protospatharii de corporis humani fabrica libri v. Oxford: Oxford University Press.

5. Klein DC, 2006 Evolution of the vertebrate pineal gland: the AANAT hypothesis. Chronobiol Int 23: 5-20.

6. Finger S, 1995 Descartes and the pineal gland in animals: a frequent misinterpretation. J Hist Neurosci 4: 166-182.

7. Srinivasant V, López-Muñoz F, De Berardis D, Álamo C, Kato TA (Eds), 2016 Melatonin, neuroprotective agents and antidepressant therapy. New Delhi: Springer. 